\title{
Adolescent Mental Health; Identifying the need and Impact of Education in Pondok Pesantren on Mental Health
}

\author{
Duna Izfanna \\ \{dunaizfanna@gmail.com\} \\ STAI Darunnajah Jakarta, Indonesia
}

\begin{abstract}
Due to the increasing need of adolescents' mental health services through the school system, school personnels have an important role in identifying the early warning signs of an emerging mental health condition and linking them with suitable mental health services and support. The present study aims to investigate the mental health condition of Pesantren students using Goodman's SDQ to 256 students. Semi-structured interviews with four teachers are been conducted to gain their views about students' mental health. The result indicates that emotional and hyperactivity/inattention problem have the highest mean score 8,88 and 8,59 respectively. Female has higher emotional problem $(9,52)$ than male students $(8,24)$, whereas class 3 Junior high school has the highest score among the other age groups $(9,27)$. Education embedded in Pesantren develop students' positive conduct, peer relationship, and prosocial behavior. However, Pesantren needs to support students to be aware of and learn to control their emotion.
\end{abstract}

Keywords: Mental health, adolescent, Pondok Pesantren, Islamic Boarding School.

\section{Introduction}

Based on WHO report, there is approximately $20 \%$ of adolescents experience mental health problems every year, most of them are depression and anxiety [1]. The risk of mental health problems among adolescents is increased. In fact, mental health is a key determinant of adolescents' healthy development. Many researches found that adolescents with good mental health tend to have ability to cope with their personal problems, positive relationship with other people, as well as successful in study. They are, later, develop into confident adults and be able to give a positive and significant contribution to the world [2].

Adolescent mental health is important in determining the quality of the nation. Adolescents who grow up in a supportive environment are human resources that can be an invaluable national asset. Although the physical maturation process pravalent occurs more rapidly in adolecence than the process of psychological maturation, human always seen as a unified whole of elements of the body and soul that need to improve the well-being and quality of life. Some types of mental health disorders which are mostly dominant in adolescence and can trigger various negative conditions such as anxiety, depression, or even the emergence of psychotic disorders.

Studies revealed that many adolescents need mental health services received through the school system, especially from teachers, administrations, and counselors. However, schools 
have risk and protective factors that may contribute to mental health of their students [3].

One of the educational systems acknowledged based on the National Educational System of Indonesia No. 20 article 302003 on the religious institution is Pondok Pesantren where all students age between 12 to 18 years old live and study together 24 hours [4]. It has become an increasingly popular choice for Indonesian parents over the last decade [5]. Since school should be safe-affirming place and can support students' mental health, especially where their home life is apart and less supportive, it is important to know the condition of Pesantren students' mental health and identify the early warning signs of mental health problems. While there are a lot of studies related to adolescents' mental health, there has been lack of research specifically exploring the condition of students' mental health in Pondok Pesantren.

The present study aims to investigate the mental health amongst students of the Pondok Pesantren, which focused on the five mental health dimensions; prosocial, hyperactivity, emotional, conduct, and peer problems relate to age group and gender. It is significant in identifying the need of mental health services that can support students' mental health in Pondok Pesantren.

\section{Mental health}

Mental health is about being in a state of good and balance in all aspects of life physically, mentally, emotionally, socially, and spiritually. It does not mean free from disease. It is the ability to live life, deal with the challenges, and face the problems. Circumstances, moods, thoughts, and well-being are continually change. Feeling off balance at times, such as, the feeling of sad, worry, fear, or doubtful, is natural but it may become problem if exist for a long period and affect life. World Health Organization and the Centre for Addiction and Mental Health reported good mental health people psychologically can usually be seen from their ability to realize their own competences, cope with the normal daily stress, work productively, and make contribution to their community [1] [6]. On the other hand, when they cannot function well psychologically due to maladaptive response of stressful situation, they may experience psychological distress. When there are changes in thinking, mood, and behavior occur over a period of time and followed with significant distress and impairs functioning, it may a sign that person is experiencing mental health problem.

Moreover, mental health and mental health problem are part of an ever changing and dynamic continuum as described in Travis'Illness/Wellness Continuum Model (see Travis' Illness-Wellness Continuum).

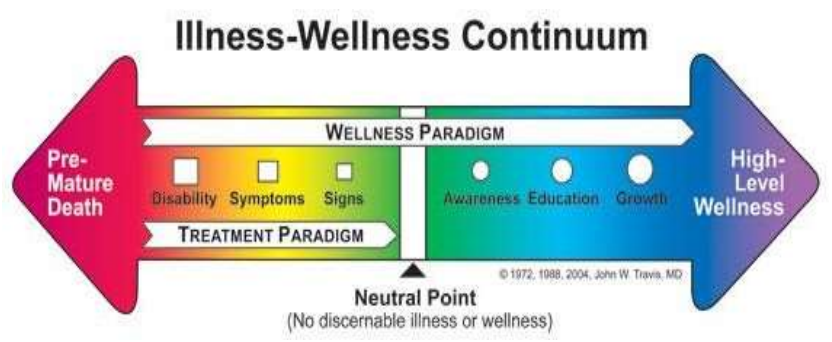

Fig. 1. Travis' Illness-wellness continuum [7]. 
The figure reflected that mental health (wellness) and mental health problems (illness) are part of a dynamic and ever-changing continuum. Moods, thoughts, and sense of well-being are continually change based on life and circumstances. Psychological distress due to inability to cope with problem leads to a negative directional association to mental health, thus, having a high level of psychological distress is a symptom of illness in mental health. The important thing is to find balance in life and have the ability to manage challenges.

In addition, there is relationship between mind and body, mental and physical. Lots of mental health problems involve both mental and physical symptoms. For instance, when a person is experiencing depression, he may experience mental symptoms such as sadness, tearfulness, and hopelessness as well as experience the physical symptoms affecting his sleep patterns, eating habits, appetite, and energy. Similarly, when another person is very nervous, he experiences mental symptoms such as fearful thoughts along with physical symptoms such as racing heart, sweaty palms, and difficulty in breathing.

There are two other terms which usually used; mental illness and mental disorder. These refers to mental health problems such as depression, anxiety, social phobia, eating disorders, schizophrenia, and personality disorders that are identified, diagnosed and treated by mental health professionals.

In this paper, the researcher uses mental health and mental health problem terms as the study discusses the balance and imbalance condition of adolescent over period of time that affect thinking, mood, and behavior especially in school. The concept of mental health consists of two domains; a) the presence of optimal functioning in physical, psychological, mental, social, and spiritual spheres and b) the absence of dysfunction or impairment in physical, psychological, mental, social, and spiritual domains [8].

\subsection{The causes of mental health problem}

In General, there are a combination of some factors contribute to the emergence, severity, and recovery of most mental health problems [7]. First is genetic factors, which related to the history of mental illness in a family. Some mental health problems can be found to occur more often in families that have a history of mental illness. Biological factors such as age and gender are also believed to affect the rates and prevalence of mental health problems. Moreover, physical illness may affect and/or be affected mental health problem. Certain symptoms of mental health problem may occur more often in people with a physical illness. For instance, people who experience a chronic physical illness may also experience depression. Another factor that mostly contribute to the emergence of mental health problem is environmental or circumstances factors such as stress due to finance difficulties, work pressure, unstable relationships, family problem, and lack of social supports.

Besides the above factors, there are other risk and protective factors which contribute to mental health of adolescents; risk and protective factors. Risk factors are those factors that are present before the emergence of a problem and increase the risk of developing a mental health problem. These factors are cumulative. For example, adolescents who have exposed to multiple risks factors such as social disadvantage, family difficulty and cognitive problems are significantly more likely to develop behavioral problems [9]. A longitudinal study based on 16,000 children and adolescents found that boys with five or more risk factors were almost eleven times tend to develop conduct disorder under the age of ten than boys with no risk factors. On the other hand, girls of a similar age with five or more risk factors were nineteen times more 
probably to develop disorder than those with no risk factors [10]. Another factor that may contribute to mental health is protective factors that may decrease the risk of developing a problem by supporting the need of adolescents and moderating the effects of the risk factors. Rutter (1985) and the hand out of Young Mind Risk and Resilience stated the risk and protective factors Child and Adolescent Mental Health (see Table 1).

Table 1. Risk and protective factors for child and adolescent mental health [11].

\begin{tabular}{|c|c|c|}
\hline & RISK FACTORS & PROTECTIVE FACTORS \\
\hline In the child/ adolescent & $\begin{array}{l}\text { - Genetic } \\
\text { - Low IQ and learning disabilities } \\
\text { - Delay in specific development } \\
\text { - Communication difficulties } \\
\text { - Difficult temperament } \\
\text { - Physical illness } \\
\text { - Academic failure } \\
\text { - Low self- esteem }\end{array}$ & $\begin{array}{l}\text { - Secure attachment experience } \\
\text { - Outgoing temperament } \\
\text { - Good in } \\
\text { - Communication and social skill } \\
\text { - Good self-control } \\
\text { - Good problem-solving skills } \\
\text { - Positive attitude } \\
\text { - Humor } \\
\text { - Experience of success and } \\
\text { - Firm of faith or spirituality } \\
\text { - Ability to reflect }\end{array}$ \\
\hline In the family & $\begin{array}{l}\text { - Parental conflict (including } \\
\text { domestic violence) } \\
\text { - Family breakdown } \\
\text { - Inconsistent/unclear discipline } \\
\text { - Hostile/rejection relationships } \\
\text { - Physical, sexual, or emotional } \\
\text { - Pare } \\
\text { - Parental physical illness } \\
\text { - disorder } \\
\text { - Death/loss }\end{array}$ & $\begin{array}{l}\text { - Good parent-child relationship or } \\
\text { - } \text { supportive adult } \\
\text { - } \text { Clear and consistent discipline } \\
\text { - Support for education } \\
\text { - Supportive long-term relationship }\end{array}$ \\
\hline In the school & $\begin{array}{ll}\text { - } & \text { Bullying } \\
\text { - } & \text { Discrimination } \\
\text { - } & \text { Lack of positive friendship } \\
\text { - } & \text { Deviant peer influences } \\
\text { - } & \text { Peer pressure } \\
\text { - } & \text { Poor student- teacher } \\
& \text { relationships }\end{array}$ & $\begin{array}{l}\text { - Clear policies on behavior } \\
\text { - Good school approach in } \\
\text { promoting mental health } \\
\text { - Positive classroom management } \\
\text { - Positive peer influences } \\
\text { - Supportive student-teacher } \\
\text { relationships }\end{array}$ \\
\hline In the community & $\begin{array}{l}\text { - Socio- economic disadvantage } \\
\text { - Homelessness } \\
\text { - Discrimination } \\
\text { - Overwhelming and significant life } \\
\text { events }\end{array}$ & $\begin{array}{l}\text { - Supportive network } \\
\text { - Good housing } \\
\text { - Good standard of living } \\
\text { - High morale school } \\
\text { - Opportunities for valued social roles }\end{array}$ \\
\hline
\end{tabular}


- Disaster, accident, war, or other significant life events

- Range of sport/leisure activities

\subsection{Adolescence mental health in Indonesia}

Adolescence, age 12 - 18 years old, is a crucial period of transition between childhood and adulthood [12] [14]. It is when a child starts to experience physical, cognitive, and socioemotional changes after puberty. Physically, the boys have more muscle and facial hair while the girls begin breast development and menstruation period. Cognitively, the adolescents begin to think logically and abstract as Piaget mentioned as formal operational thought. They start to develop their logical reasoning, decision making and problem-solving skill [13]. Sometimes, they experiment with different roles, activities and behaviors to develop a sense of self and personal identity. In order to achieve their virtue, they try to know themselves better and having positive value about themselves. Otherwise, when they experience failure to understand themselves or having negative values about themselves may cause crisis identity [14]. For instance, many adolescents tend to behave riskily by experimenting with substances such as illicit drugs, tobacco, and alcohol. Adolescents, socially, spend more time outside of their houses and spend more time with their peers, and they are also more concerned about what their friends say rather than taking an advice from parents and teachers. They are expected to be more responsible than before, but not as independent as adults because they are still under supervision from the parents.

Adolescents are also challenged with numerous events and conditions in their daily life, both normative in nature such as school tasks or peers, as well as non-normative events like violence and bullying. Those normative and non-normative events are stressful enough for adolescents and may cause them a mental health problem, such as depression [15]. Previous researches revealed that adolescents in senior high school with mental health problems have difficulties performing daily activities, low academic achievement [16], and in few cases is associated with suicide ideation [17]. Therefore, the mental health condition of adolescents should be more paid attention since the effects of mental health in adolescents tend to persist through adulthood.

According to the Central Statistical Bureau of Indonesia, the total number of youths in Indonesia in 2013 were approximately 20.6 million for male and 19,9 million for female, which means about $16.7 \%$ of the total population in Indonesia are adolescents [18]. Most Indonesian adolescents still live with their parents unless they have to leave home for educational or vocational reasons. A large survey of The Global School-Based Student Health Survey (GSHS) project that was conducted collaboratively by Indonesia Ministry of Health, Indonesia Ministry of Education, and WHO on 3.116 Indonesian students aged between 13-16 years old in 49 middle schools related to mental health condition found that $8.6 \%$ of the adolescents reported feeling lonely while $7.7 \%$ of them reported feeling worried and unable to sleep at night. In addition, there was about $20-22 \%$ of adolescents stated feeling sad and hopeless most of the time that they stopped doing their daily activities. It also found that most Indonesian adolescents are also unaware about how to deal with mental health problems because of their limited awareness, information and knowledge about mental health issues; also, stigmatization that put people with mental health problems as negative (Soerachman, 2007 as cited in Budhi Utama, 
2014) [19].

Budhi Utama in his own study on "Mental health and community violence among adolescents in Indonesia; school-based study" also found out that $64.7 \%$ of adolescents experienced psychological distress, which is higher than other epidemiology studies among adolescent populations. From those percentages, girls found tend to exhibit psychological distress than boys. He also argued that in designing mental health policy and prevention program school should also consider gender and school factors [19].

\section{The Context; Pondok Pesantren}

The term Pondok literally comes from Arabic word "funduq" means humble house and by extension, it means Islamic religious boarding school [20]. The term Pondok is also used in Malaysia and Southern Thailand, while Pesantren is used most often in Indonesia, specifically in Java. Sometimes the two terms are combined as "Pondok Pesantren" to make clear that it refers to "a traditional Islamic boarding school and not merely a religious day school (such as the more modern madrasa)" [20]. However, the researcher recommends that Pondok, Pesantren, and Pondok Pesantren are synonymousaImam Zarkasyi stated that those terms refer to Islamic educational institution which has a Pondok or boarding system in where the central figure of the institution (as teacher, educator, and advisor) is a kyai or religious leader, its central element is the mosque, and based on Islamic teaching that mold students' activities (1994 cited in Abdullah Syukri Zarkasyi, 2005) [21].

Pondok Pesantren can be found in some Islamic countries and is usually called "Pondok" in Southern Thailand and Malaysia, also "madrasa Islamia" (madrasa) in India, Pakistan and many of the Arabic world. Although to some extent differ, the pedagogical ideal of Pondok Pesantren includes intellectual as well as moral and character aspects in which the students is drawn ever closer to God as it is stated by Zamakhsyari Dhofier that,

Education in a Pesantren does not seek.... (only) to fill the minds of students with information, but to refine their morals, educate their spirits, propagate virtue, teach propriety, and prepare students for a life of sincerity and purity. Every student is taught to regard religious ethics above all else. The student's goal in education must not to obtain power, money, or glory; learning is an obligation, a dedication to God [22]

In the earlier development of Pondok Pesantren in Indonesia, Pondok Pesantren was traditionally taught an almost exclusively religious teaching and was the training grounds for religious leaders (Zamakhsyari Dhofier; 1999; Anderson, 1990 as cited in Lukens-Bull, 2005) [22] [23]. Nowadays, it has been acknowledged as one of the educational institutions based on the National Educational System of Indonesia No. 20 article 302003 on the religious institution [24], and it has become an increasingly popular choice for Indonesian parents over the last decade (Diknas 2006 as stated in Direktorat Jenderal Pendidikan Islam, kementerian Agama RI, 2009) [5].

The context of the present study is at a private Pondok Pesantren, an Islamic boarding school in Indonesia. The researcher decided to focus on Pondok Pesantren due to the need of the school and the lack literature on students' mental health in Indonesia, specifically Pondok Pesantren. This study investigates the conditions of students' mental health based on 5 
dimensions namely prosocial behavior, hyperactivity /inattention, emotional, conduct, and peer relationship. It also aims to explore the differences amongst gender and age group (class).

\section{Methodology}

The study aims to investigate the mental health of students at the Pondok Pesantren. 256 students are selected using stratified sampling technique based on 4 age groups (class 1 and 3 junior high school \& class 1 and 3 senior high school) as well as gender (male and female). Four senior teachers of the Pondok Pesantren who have access to the information related to the purpose of study and closely involved in students' activities are invited to discuss through interviews to gain their views and experiences about students' mental health.

The Instrument used in the present research is the Strengths and Difficulties Questionnaire (SDQ). It is a brief mental health and behavioral screening questionnaire about 3-16-year olds. It is widely used in many nations (Levitt, Saka etal.2007) and exists in several versions to meet the needs of researchers, clinicians and educationalists. The instrument is divided into five dimensions namely emotional symptoms, conduct problems, hyperactivity/inattention scale, and peer problem scale. The SDQ scores can be used as continuous variables as well as categorized scores. The categorized scores define as normal (0-15), borderline (16-19), and abnormal (20-40).

This study is analyzed through descriptive and inferential statistics to investigate the mental health of the students and the differences with respect to their gender and age group (class). All the responses of the students are coded, keyed in, and analyzed using SPSS; then, related them with the teachers' answers during the interview sessions.

\section{Result and discussion}

The demographic characteristics of the sample are described in table 2 . In this study, the samples of the students are equally distributed amongst the age group (class) and gender, whereas, the teachers are purposively chosen based on their seniority, the duration of the teaching, and their involvement in students' activities in the Pondok Pesantren. 
Table 2. Demographic characteristics of the sample.

\begin{tabular}{|c|c|c|c|}
\hline Sample & Males & Females & Total \\
\hline \multicolumn{4}{|c|}{ Students (Junior High School) } \\
\hline Class 1 & 32 & 32 & 64 \\
\hline Class 3 & 32 & 32 & 64 \\
\hline \multicolumn{4}{|c|}{ Students (Senior High School) } \\
\hline Class 1 & 32 & 32 & 64 \\
\hline Class 3 & 32 & 32 & 64 \\
\hline \multicolumn{4}{|l|}{ Teachers } \\
\hline Teacher & 2 & 2 & 4 \\
\hline
\end{tabular}

The result indicates that all of the students are categorized into normal range from 5 to 15. Amongst the five dimensions of mental health, emotional problem and hyperactivity/inattention problems have the highest mean score 8,88 and 8,59 respectively (see Table 3 and Figure 2). This is concurrent with the statements of the teachers that generally all students are good, but some of them seems have emotional and peer problems (T, SF, FE, EM). The following table and figure show the descriptive statistics of each dimension of students' mental health.

Tale 3. Descriptive statistics of each dimension of students' mental health.

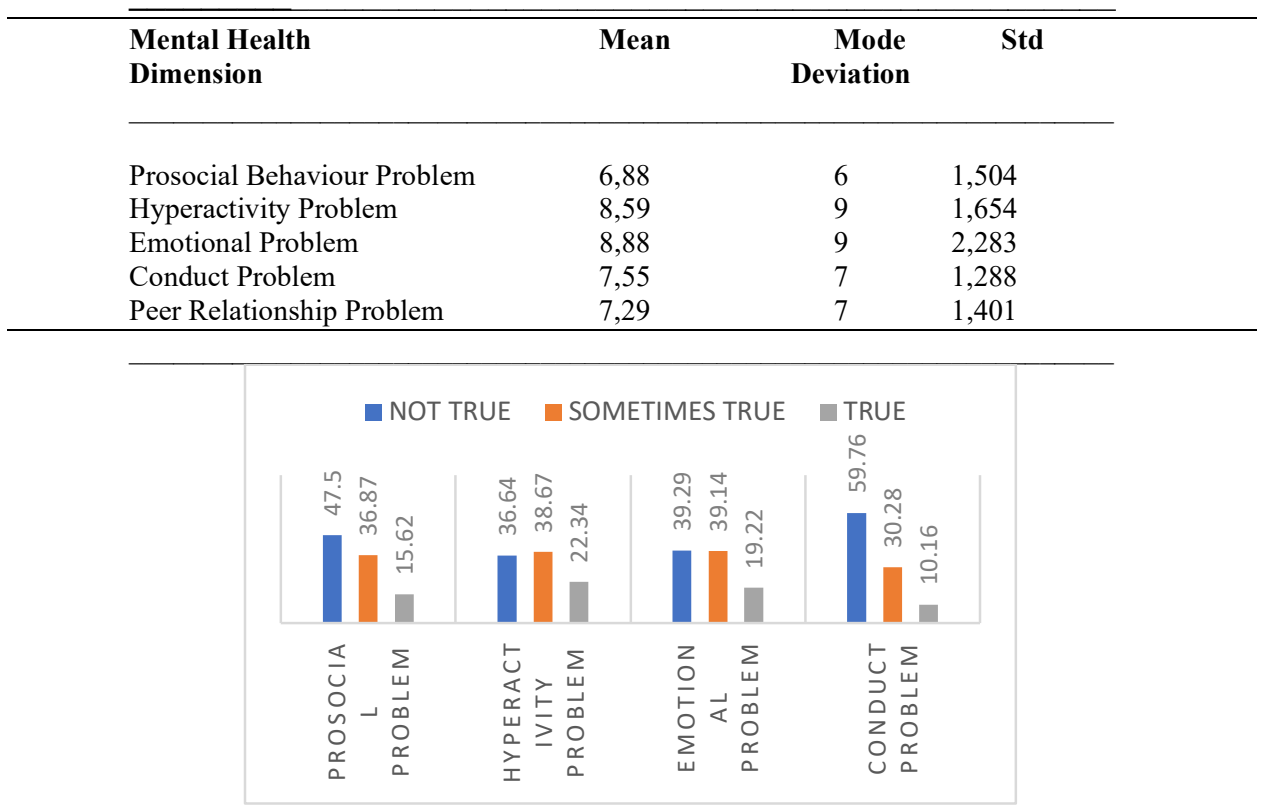

Fig. 2. Frequency of students' mental health problems (percentage). 
Based on the Table and Figure, it finds out that the lowest scores are prosocial behavior problem $(6,88)$ and peer relationship problem $(7,44)$. It is in line with the teachers' views that students in the Pondok Pesantren are used to care and help one another. The students usually form a close relationship with their roommates whom they stay and spend most of the time together. Despite occasional minor quarrels and misunderstandings, they influence one another. Since they live together, they can easily observe the others' character, attitudes, and behaviors.

Friends are the most influential factor because students spend 24 hours for seven days with their friends ( $T, 32-36)$

Studying and socializing with teachers, staying together and making friends with the other students, as well as trying to manage their own life for 24 hours, more or less, may develop their prosocial behavior and good peer relationship. For instance, staying together for a long period of time with the other students from different backgrounds stimulate them to develop close and intimate relationships (EM, 34). In addition, one of the teachers tells of his experiences that if his student has food (especially when parents come or send package), he would share with his friends or roommates (SE, 64). These results support Rutter's (1985) statement of Young Mind Risk and Resilience that school has protective factors for students mental health, one of them is sense of belonging positivie peer influences.

Furthermore, in this Pesantren all students have to follow their daily duties and activities every day, especially religious practical duties such as performing congregational prayers at the mosque, reciting al-Qur'an after Shubuh, Ashar, and Maghrib prayers, participating in extracurricular activities, as well as studying are included as obligations and become a part of Pondok Pesantren's rules and regulations. These stimulate and develop their positive conducts or behaviors as acknowledged by Basheer (1982) that the establishment of ibadah or the practical duties of Islam should be included in education to attain the goodness of conduct and character. This might explain the reason of the low score of conduct problem among them $(7,55)$.

The study also shows that female students have higher emotional problem $(9,52)$ than male students $(8,24)$ (see Table 4). This finding is similar with Budi Utama's study (2014) study on "Mental health and community violence among adolescents in Indonesia; school based study" that girls found tend to exhibit psychological distress (the most common type of emmotional problem) than boys. In addition, among the age groups, class 3 Junior high school has the highest score $(9,27)$ (see table 5).

Table 4. Mean distribution of students mental health according to gender.

\begin{tabular}{lcc}
\hline Dimension & Male & Female \\
\hline Prosocial Behavior Problem & 7,02 & 6,74 \\
Hyperactivity Problem & $\mathbf{8 , 5 2}$ & 8,66 \\
Emotional Problem & 8,24 & $\mathbf{9 , 5 2}$ \\
Conduct Problem & 7,63 & 7,48 \\
Peer Relationship Problem & 7,44 & 7,13 \\
& & \\
\hline
\end{tabular}


Table 5. Mean distribution of students mental health according to age group.

\begin{tabular}{lcccc}
\hline & Junior High School & \multicolumn{2}{c}{ Senior High School } \\
Class & $\mathbf{1}$ & $\mathbf{3}$ & $\mathbf{1}$ & $\mathbf{3}$ \\
& & & & \\
\hline Prosocial Behavior Problem & $\mathbf{7 , 0 9}$ & 7,06 & 6,59 & 6,78 \\
Hyperactivity Problem & 8,55 & 8,31 & 8,72 & $\mathbf{8 , 7 8}$ \\
Emotional Problem & 9,02 & $\mathbf{9 , 2 7}$ & 8,89 & 8,34 \\
Conduct Problem & 7,53 & $\mathbf{7 , 5 9}$ & 7,25 & 7,84 \\
Peer Relationshiip Problem & $\mathbf{7 , 5 5}$ & $\mathbf{7 , 0 2}$ & 7,05 & 7,53 \\
& & & & \\
\hline
\end{tabular}

\section{Conclusion}

The present study aims to investigate mental health of students at one of private Pondok Pesantrens in Jakarta, Indonesia using Goodman's Strength and Difficulties Questionnaire (SDQ). Therefore, the findings apply only to adolescents who attend to this Pondok Pesantren. However, this study could be adapted and used as the a baseline data of mental health situations in Pondok Pesantren or Islamic boarding school, especially in Indonesia with similar caharacteristics.

The result indicates that all of the students of Pondok Pesantren are categorized into normal $(0-15)$ in which emotional problem and hyperactivity problem have the highest mean score 8,88 and 8,59 respectively. Female sudents need more guidance in dealing wih their emotional problems $(9,52)$ than male $(8,24)$, whereas class three Junior High School in the Pondok Pesantren has the highest schore of emotional amongst other age groups $(9,27)$.

Based on the findings, the researcher suggests that the Pondok Pesantren should aware on the difference conditions of students' mental health relate to their age group and gender. It might help the Pondok Pesantren to provide the most suitable services and support of mental health. Enhancing mental health in Pondok Pesantren where students live 24 hours a day can maximize and strengthen well-being of students.

Future studies need to expand the study to include other Pondok Pesantrens, explore related factors, also on how to develop and enhance students' positive mental health in Pondok Pesantren.

\section{References}

[1] World Health Organization. Mental health: Strengthening our response. Fact Sheet N 220. WHO Media Centre. Retrieved, 31 March 2013 from: http://www.who.int/mediacentre/factsheets/fs220/en/. (2010, September)

[2] Patel, Flisher, Hetrick, \&McGorry. Mental health of young people: a global public-health challenge. The Lancet, 369(9569), 1302-1313. (2007)

[3] Rutter, M. Resilience in the face of adversity. Protective factors and resistance to psychiatric disorder. British Journal of Psychiatry. Vol. 147, pp. 598-611. (1985)

[4] Direktorat Pendidikan Nasional. Undang-undang system pendidikan nasional. Retrieved at August 1, 2010 from http://www.inherent- dikti.net/files/sisdiknas.pdf. (2003) 
[5] Direktorat Jenderal Pendidikan Islam, Kementerian Agama RI. Wajah lain Pondok Pesantren. Retreived at March 28, 2010 from http://pendis.kemenag.go.id/index.php?a=artikel\&id2=pendis. (2009)

[6] The Centre for Addiction and Mental Health. Definition: Mental health vs mental health problems, mental wellness vs mental illness. Retrieved at August 10, 2016 from http://www.camh.ca/en/education/teachers_school_programs/secondary_education/Pages/secondary_ educatio n.aspx. (2003).

[7] Payton, A.R. Mental health, mental illness, and psychological distress: same continuum or distinct phenomena?. Journal of Health and Social Behavior, 50(2), 213-227. (2009)

[8] Dix, Katherine L., Askell-William, Helen., \& Lawson, Michael J. Different measures, different informants, same outcomes? Investigating multiple perspectives of primary school students' mental health. Centre for Analysis of Educational Futures, School of Education, Flinders University, South Australia. (2008)

[9] Brown, E., Khan, L. and Parsonage, M. A Chance to Change: Delivering effective parenting programmes to transform lives. Centre for Mental Health. (2012)

[10] Murray, J. J. Very early predictors of conduct problems and crime: results from a national cohort study. Journal of Child Psychology \& Psychiatry, 51(11), pp 1198-1207. (2010)

[11] Rutter, M. Resilience in the face of adversity. Protective factors and resistance to psychiatric disorder. British Journal of Psychiatry. Vol. 147, pp. 598-611. (1985)

[12] Atwater, E. Adolescence 3rd edition. New Jersey, NJ: Prentice-Hall. (1992).

[13] Dupre, D. Cognitive development for adolescents in a global era: A social justice issue?. In D.P. Swanson, M.C. Edwards, M.B. Spencer (Ed), Adolescents development during a global era (pp. 6392). United States of America, USA: Elsevier inc. (2010).

[14] Swanson, M.C. Edwards, M.B. Spencer (Ed), Adolescents development during a global era (pp. 341-363). United States of America, USA: Elsevier inc. (2010)

[15] Siantz, M.L.L \& Dovydaitis,T. Critical health issues during adolescence. In D.P. Swanson, M.C. Edwards, M.B. Spencer (Ed), Adolescents development during a global era (pp. 341-363). United States of America, USA: Elsevier inc. (2010)

[16] Rothon, C., Head, J., Clark, C., Klineber, E., Cattell, V., \& Stansfeld., S. The impact of psychological distress on the educational achievement of adolescents at the end of compulsory education. Soc Psychiatr Epidemiol, 44(5), 421-427. (2009)

[17] Patel, V., Flisher, A. J., Hetrick, S., \& McGorry, P. Mental health of young people: a global publichealth challenge. The Lancet, 369(9569), 1302-1313. (2007)

[18] Badan Pusat Statistik. Statistic Indonesia. Retrieved 28, March 2014. From http://www.datastatistik-indonesia.com/portal/index.php?option=com_proyeksi\&task=show\&Itemid= 172. (2013)

[19] Budhi Utama. Mental health and community violence amongst adolescents in Indonesia (schoolbased study). Thesis submitted in Institute of Health and Society, Universitas Osloensis. (2014)

[20] Denny, F.M. Pesantren. In Gibb, H.A.R., et. Al. (Ed.). The encyclopaedia of Islam Vol. VIII. Leiden: E.J. Brill. (1995).

[21] Abdullah Syukri Zarkasyi, KH. Gontor dan pembaharuan pendidikan pesantren. Jakarta: PT. Grafindo Persada. (2005).

[22] ZamakhsyariDhofier. The Pesantren tradition: The role of the Kyai in the maintenance of traditional Islam in Java. Temple, Arizona: Program for Southeast Asian Studies. (1999).

[23] Lukens-Bull, Ronald A. Teaching morality; Javanese education in a globalizing era. Jacksonville: University of North Florida. Retrieved at March 4, 2009 from http://www.uib.no/jais/v003ht/03-026047Lukens1.htm. (2005).

[24] Direktorat Pendidikan Nasional. Undang-undang system pendidikan nasional. Retrieved at August 1, 2010 from http://www.inherent- dikti.net/files/sisdiknas.pdf. (2003). 